\title{
Special Issue "Multiscale Impacts of Anthropogenic and Climate Changes on Tropical and Mediterranean Hydrology"
}

\author{
Gil Mahé ${ }^{1}\left(\mathbb{D}\right.$, Luc Descroix ${ }^{2,3, *}$, Alain Laraque ${ }^{4}$, Olivier Ribolzi ${ }^{5}$ and Guillaume Lacombe ${ }^{6}(\mathbb{D}$ \\ 1 IRD HSM, Case MSE, Université Montpellier, 300 avenue Emile Jeanbrau, 34090 Montpellier, France; \\ gilmahe@hotmail.com \\ 2 UMR PALOC IRD/MNHN/Sorbonne Université, Museum National d'Histoire Naturelle, 75231 Paris, France \\ 3 LMI PATEO, UGB, St. Louis 46024, Senegal \\ 4 IRD, GET-UMR CNRS/IRD/UPS-UMR 5562 du CNRS, UMR 234 de l'IRD, 900 rue J.F. Breton, \\ 34090 Montpellier, France; alain.laraque@ird.fr \\ 5 Géosciences Environnement Toulouse, Université de Toulouse, CNES, CNRS, IRD, UPS, 31400 Toulouse, \\ France; olivier.ribolzi@ird.fr \\ 6 CIRAD, UMR G-EAU, Université Montpellier, AgroParisTech, CIRAD, INRAE, Institut Agro, IRD, \\ 34398 Montpellier, France; guillaume.lacombe@cirad.fr \\ * Correspondence: luc.descroix@ird.fr
}

check for

updates

Citation: Mahé, G.; Descroix, L.; Laraque, A.; Ribolzi, O.; Lacombe, G. Special Issue "Multiscale Impacts of Anthropogenic and Climate Changes on Tropical and Mediterranean Hydrology". Water 2021, 13, 491. https://doi.org/10.3390/w13040491

Received: 14 January 2021

Accepted: 8 February 2021

Published: 14 February 2021

Publisher's Note: MDPI stays neutral with regard to jurisdictional claims in published maps and institutional affiliations.

Copyright: (c) 2021 by the authors. Licensee MDPI, Basel, Switzerland. This article is an open access article distributed under the terms and conditions of the Creative Commons Attribution (CC BY) license (https:/ / creativecommons.org/licenses/by/ $4.0 /)$.

\section{Introduction}

Most tropical and Mediterranean areas, landscapes, soils, and territories are experiencing new vulnerabilities, facing global warming [1] and accelerating changes in land-use in all kinds of ecosystems [2]. Long droughts, dry spells, rainfall intensification, and an increase in the number of storms and cyclones make agriculture as well as land management and water and sediment control more difficult. In many regions, the population increase is too strong to allow cropping and rural activities to easily reach Boserupian behavior. The intensification of the climatic cycle induced by global warming commonly leads to an acceleration of the hydrological cycle, increasing the occurrence of flooding, inundation, as well as droughts and water shortages $[3,4]$. Human actions and overall rural activity can strongly modify water runoff and infiltration, then water balance, by increasing infiltration and buffering the water cycle, or on the contrary, by reducing the soil permeability, increasing runoff, and accelerating the water cycle [5-7]. Rural practices are commonly suspected to decrease the soil water-holding capacity. This could lead to a rise in flooding occurrence and intensity downstream, and could cause an edaphic drought even in areas where no climatic drought is observed.

These kinds of changes influence hydrology and erosion/sedimentation processes, with implications for various risks: food insecurity, natural disasters (landslides, flood damage), water shortages, and pathogenic contaminations. The accelerating pace of these environmental changes leaves limited time for adaptation. While the need for "climate change adaptation" is recognized, there is also a need for land-use change adaptation and a better assessment of contamination risks [8]. To date, there is limited understanding of the processes linking land-use management to these risks.

There is a need to understand causal chains of processes, from land-use, vegetation structure, soil, erosion, hydrological connectivity (surface and subsurface) infiltration, and their related risks in order to better manage these risks and reduce them [9]. Multi-scale approaches are relevant because there are multi-scale impacts; micro-plots and hillslopes are relevant to understanding processes controlling soil detachment and the partition of rainfall into surface and subsurface flow in relation with interacting land-use and soil surface dynamics. At the watershed level, local dynamics translate into risks of hydrological extremes, erosion, and contamination, threatening downstream ecosystems, infrastructures, and populations [10]. 


\section{Spatial and Temporal Scales}

This Special Issue presents results of studies from many different parts of the world, mainly from Africa and Europe, including the Mediterranean area, Asia [11,12], and South America [13]. The papers showcase studies under equatorial, tropical humid, semi-arid, and Mediterranean climate. All spatial scales are investigated, from the very local scale of gullies in Spain [14] to the largest rivers of the world, the Amazon and Orinoco rivers in South America [13] and Congo River in Central Africa [15]. The whole African continent is also the topic of the paper of Dieulin et al. [16] (2020), presenting a new continental monthly rainfall dataset at the half-degree square scale covering the years 1940 to 1999, computed only from observations from ground-based stations. Many time scales are also investigated, from daily events $[17,18]$ to interannual variability $[15,16]$.

The topics studied cover a large panel of hydrological questions. Many of them deal with the study of time series variability, rainfall [16], discharges $[19,20]$, sediment transport [11-13,21], recession coefficient [22,23], climate change impacts [17,24], or anthropogenic impacts $[2,11,20,21]$. Drought is also a topic of notable interest in Mediterranean and tropical areas [23-25].

This Special Issue includes several papers dealing with topics at the continental or subcontinental scale. The quality of rainfall data is, for instance, of very high importance to improve the efficiency of hydrological modeling through calibration/validation experiments. The HydroSciences Montpellier Laboratory (HSM) has a long experience in collecting and managing hydro-climatological data. Dieulin et al. [16] present the results of several years of studies to elaborate a reference dataset in order to build monthly rainfall grids over the African continent over a period of 60 years (1940-1999). The large quantity of data collected (about 7000 measurement points) allowed for interpolation using only ground-based observed data, with no statistical use of a reference period. The mean annual grid was compared to the Climate Researh Unit (CRU) grid with HSM_SIEREM data (database HydroSciences Montpellier_Système d'Information Environnementales pour les Ressources en Eau et leur Modélisation) being closer to the observed rain gauge values. The statistical tests, computed on the observed and gridded data, detected a rupture in the rainfall regime around 1979/1980, at the scale of the whole continent, which seems in line with some results in different parts of Africa (North Africa [21]; Congo basin in Central Africa [15]). At the monthly time scale, the most widely observed signal over the period of 1940-1999 was a significant decrease of the austral rainy season between March and May, which has not been previously well documented.

\section{Hydrosedimentary Regimes of the Three Largest Rivers of the World}

Laraque et al. [13,15] also deal with very large scales, as they cover the three largest rivers of the world by discharge value, all located in equatorial-tropical areas, the Amazon and Orinoco rivers in South America and Congo River in Central Africa. These papers highlight low-documented areas. In South America, the study is focused on the very curious and much unknown Casiquiare Canal, linking both the giant Orinoco and Amazon rivers, investigated during a dedicated international expedition in 2000 [13]. The results presented for the Congo River cover more than one century of measurements and represent the most recently documented synthesis on the Congo River water, with an investigation of dissolved and suspended matters fluxes [15]. In the flat basin of the Congo River, the absence of mountain chains and the extent of its coverage by dense rainforest explains how chemical weathering (10.6 t km${ }^{-2}$ year $^{-1}$ of total dissolved solids) slightly predominates physical erosion $\left(9.3 \mathrm{t} \mathrm{km}^{-2}\right.$ year -1 of total suspended solids), followed by organic production ( $4.5 \mathrm{t} \mathrm{km}^{-2}$ year ${ }^{-1}$ of dissolved organic carbon). As the interannual mean discharges are similar, it can be assumed that these interannual averages of material fluxes, calculated over the longest period (2006-2017) of monthly monitoring of its sedimentology and bio-physical-chemistry, are therefore representative of the flow record available since 1902 (with the exception of the wet decade of 1960). Without neglecting the indispensable in situ work, the contributions of remote sensing and numerical modelling should be 
increasingly used to try to circumvent the dramatic lack of field data that persists in this basin.

Regarding the South American rivers, the aim is to present a review and synthesis of the hydrological and sedimentological knowledge of the world's longest natural defluence, the Casiquiare channel, including its first hydrosedimentary, which was conducted 9-12 September 2000 at the bifurcation and mouth during the expedition 'Humboldt-Amazonia $2000^{\prime}$. This fluvial system connects the two largest river of South America and the main conclusions of this study explain why the Casiquiare can be qualificated of a 'cameleon' channel which is taking a significant proportion of flow (20\% to $30 \%)$ from the Upper Orinoco basin to the Amazon basin.

\section{Climatic or Anthropogenic Impacts on River Regimes}

In several studies, authors search for the possible origin, climatic or anthropogenic, of the interannual variability observed in the times series of rainfall and discharges. In Central Africa, Ebodé et al. [20] study the impact of anthropization and climate change on two forested watersheds (of Ntem and Nyong) in the south of the country, under equatorial and sub-equatorial climates. The results of this study show that in Central Africa, annual discharges have decreased significantly since the 1970s, and yet the decline in annual rainfall does not become significant until the 2000s. The discharges of the rainy seasons (spring and autumn) recorded the most important changes, following variations in the rainfall patterns of the dry seasons (winter and summer) that preceded them. Winters experienced a significant decrease in precipitation between the 1970s and 1990s, which caused a drop in spring flows. Their rise, which began in the 2000s, is also accompanied by an increase in spring flows, which nevertheless seems to have been very moderated in the case of the Nyong. Conversely, between the 1970s and 1990s, there was a joint increase in summer rainfall and autumn flows. A decrease in summer rainfall was noted since the 2000s, and is also noticeable in autumn flows. Maximum flows have remained constant on the Nyong despite the slight drop in rainfall. This seems to be a consequence of changes in land-use patterns (diminution of forest and increases in the amount of impervious areas). The decrease in maximum flows noted on the Ntem could be linked to the slight drop in precipitation during the rainy season that generates it. Natural factors, such as the general decrease in precipitation during the winter and the reduction in the area occupied by water bodies, could justify the decrease in minimum flows observed in the two watersheds.

Amoussou et al. [17] study the impact of climate change from regional climate model outputs on extreme rainfall events for the Mono River, between Benin and Togo. This research characterizes the future changes in extreme rainfall and air temperature from observational datasets and regional climate models (RCMs) that were used to analyze climatic variations in space and time and fit a generalized extreme value (GEV) model to investigate the extreme rainfalls and their return periods. The authors show that the annual maxima of daily precipitation is expected to increase by 2050 and could be of benefit to the ecosystem services and socioeconomic activities in the Mono River basin, but could also be a threat due to unpredictable consequences of more extreme events.

Bodian et al. [18] investigate the recent trend of hydroclimatic variables in the Senegal River basin based on 36 rain gauge stations and three hydrometric stations not influenced by hydraulic structures. They concentrate on the description of insight views regarding the consequences of the changes in rainfall regimes on the hydrological characteristics of several stations of the Senegal River over several decades. The Mann-Kendall and Pettitt's tests were applied for the annual rainfall time series from 1940 to 2013 to detect the shift and the general trend of the annual rainfall. In addition, trends of the average annual flow rate (AAFR), maximum daily flow (MADF), and low flow rate (LFR) were evaluated before and after annual rainfall shift. 


\section{Changes in Hydrological Cycle and Water Quality}

Descroix et al. [24] explore the evolution of the salinity in the inverse estuaries of two Senegalese rivers in West Africa since the end of the 1968-1993 drought. The results show that in both estuaries, the mean water salinity values have markedly decreased since the end of the drought. However, the Saloum estuary remains a totally inverse estuary, while for the Casamance River, the estuarine turbidity maximum (ETM) is the location of the salinity maximum, and it moves according to the seasons. The West African mangroves are among the few in the world that have been markedly increasing since the beginning of the 1990s and the end of the peak of the dry period in West Africa, as mangrove growth is favored by the relative salinity reduction in this area.

Going further inside the hydrological cycle, Descroix et al. [23] discuss the recent dynamics of the Fouta Djallon's hydrological functioning. The evolution of the runoff and depletion coefficients are analyzed as well as their correlations with the rainfall and vegetation cover. The latter is described at three different space scales and with different methods. Twenty-five years after the end of the 1968-1993 major drought, annual discharges continue to slowly increase, nearly reaching the long-term average, as natural reservoirs which were emptied to sustain streamflows during the drought have been replenishing since the 1990s, explaining the slow increase in discharges. However, another important trend has been detected since the beginning of the drought, namely the increase in the depletion coefficient of some of the Fouta Djallon upper basins, as a consequence of the reduction in the soil water-holding capacity. After observing that this increase and subsequent decrease in the depletion coefficient is localized in parts of the Upper Niger basin and the Konkouré basin, this paper identifies the factors possibly linked with the basins' storage capacity trends. Two pieces of "good news" are highlighted: first, the densely populated areas of the summit plateau are also shown to be the ones where vegetation cover is not threatened and where the ecological intensification of rural activities is ancient; second, most of the river basins providing the Sahel with freshwater have recovered the discharge and soil water-holding capacity levels that they had before the drought.

Bader et al. [22] develops a methodology to compare the evolution of the runoff and depletion coefficients in the Senegal Niger and Gambia rivers. The seasonal flow recession observed at 54 gauging stations in these basins from 1950 to 2016 is represented by empirical and usual conceptual models that express the daily depletion factor (K). Compared to conventional conceptual models, an empirical model representing $\mathrm{K}$ as a polynomial of the decimal logarithm of discharge $(\mathrm{Q})$ is shown to provide better representations of $\mathrm{K}$ and better discharge forecasting at horizons from 1 to 120 days for most stations. The relationship between specific discharge (Qs) and $\mathrm{K}$, not monotonous, is highly homogeneous in some sub-basins but differs significantly between the Senegal and Gambia basins on the one hand and the Niger basin on the other.

Concerning the Mediterranean, three studies deal with complementary topics: rainfall, runoff, and erosion.

Cavus and Aksoy [25] study the spatial drought characterization for the Seyhan River in Turkey, investigating the spatial and temporal characteristics of drought using standardized precipitation index and different spatialization techniques. They primarily use the standardized precipitation index (SPI) from monthly precipitation data at a 12-month time scale for 19 meteorological stations scattered over the river basin. The drought with the highest severity in each year is defined as the critical drought of the year. Frequency analysis was applied on the critical drought to determine the best-fit probability distribution function by using the total probability theorem. The sole frequency analysis is insufficient in drought studies unless it is numerically related to other factors, such as the severity, duration, and intensity. Yilmaz et al. [19] use statistical methods for daily streamflow estimation at ungauged basins in Turkey. The single donor station drainage area ratio (DAR) method, the multiple-donor stations drainage area ratio (MDAR) method, the inverse similarity weighted (ISW) method, and its variations with three different power parameters $(1,2$, and 3$)$ are applied to the two main sub-basins of the Euphrates basin 
in Turkey to estimate daily streamflow data. Each station in each basin is considered in turn as the target station where there are no streamflow data. Their results show that MDAR and ISW give improved performance compared to DAR for estimating the daily streamflow for seven out of eight target stations in the Middle Euphrates basin and for four out of seven target stations in the Upper Euphrates basin. Higher Nash-Sutcliffe Efficiency (NSE) values for both MDAR and ISW are mostly obtained with the three most physically similar donor stations in the Middle Euphrates basin and with the two most physically similar donor stations in the Upper Euphrates basin. Hout et al. [14] use lidar data to survey the evolution of the morphology of gullies on the slopes of a lake in semi-arid southern Spain. Due to the nature of the geological formations at the lakeshore level, gully erosion is very high and leads to silting up of the dam. This study was conducted to estimate the sediment input from the bank gullies. The combination of two configurations of nadir and oblique photography allowed the authors to obtain a complete high-resolution modeling of complex bank gullies with overhangs. They develop a complex methodology to allow erosion to be quantified between two dates at the gully scale. The results reveal significant lakeshore erosion activity by bank gullies, since the annual inflow from the banks is estimated at $39 \mathrm{t} \mathrm{ha}^{-1}$ year ${ }^{-1}$.

\section{Erosion, Land Cover, and Land Use}

Three more papers investigate erosion surveys and their relationships with land cover and land use. Two of these studies use spatial data to retrieve land-cover characteristics.

In northern Laos (Song et al. [12]), the replacement of traditional crops by tree plantations, such as teak trees, has led to a dramatic increase in floods and soil loss and to the degradation of basic soil ecosystem services, such as water filtration by soil, fertility maintenance, etc. The authors [12] hypothesized that conserving understory under teak trees would protect soil, limit surface runoff, and help reduce soil erosion. It is shown that teak planting does not have an anti-erosive power at all; this land cover shows the highest runoff coefficient and soil loss, associated with the highest crusting rate; this is due to the kinetic energy of rain drops falling from the broad leaves of the tall teak trees down to bare soil, devoid of plant residues, thus leading to severe soil surface crusting and soil detachment. Hence, teak tree plantation owners could divide soil loss by 14 by keeping understory, such as broom grass, within teak tree plantations. Overall, promoting understory, such as broom grass, in teak tree plantations would (1) limit surface runoff and improve soil infiltrability, thus increasing the soil water stock available for both root absorption and groundwater recharge, and (2) mitigate soil loss while favoring soil fertility conservation.

Ma et al. [11] study the hydrological impacts of expanding rubber plantations on a watershed of $100 \mathrm{~km}^{2}$ in the Xishuangbanna prefecture, Yunnan Province, China. The influence of land-cover change on streamflow recorded since 1992 was isolated from that of rainfall variability using cross-simulation matrices produced with the monthly lumped conceptual water balance model GR2M. Their results indicate a statistically significant reduction in wet and dry season streamflow from 1992 to 2002, followed by an insignificant increase until 2006. Analysis of satellite images from 1992, 2002, 2007, and 2010 shows a gradual increase in the areal percentage of rubber tree plantations at the watershed scale. However, there were marked heterogeneities in land conversions (between forest, farmland, grassland, and rubber tree plantations), and in their distribution across elevations and slopes, among the studied periods. Possible effects of this heterogeneity on hydrological processes, controlled mainly by infiltration and evapotranspiration, are discussed in light of the hydrological changes observed over the study period. The authors suggest pathways to improve the eco-hydrological functionalities of rubber tree plantations, particularly those enhancing dry-season base flow, and recommend how to monitor them.

In Morocco, North Africa, Ezzaouini et al. [21] assess the sediment inputs into the dam's lake on the Bouregreg River. They apply the Modified Universal Soil Loss Equation (MUSLE) model to predict solid transport, calibrated by two years of solid transport 
measurements from four main gauging stations at the entrance of the Sidi Mohamed Ben Abdellah dam. The application of the MUSLE on the basin demonstrated relatively small differences between the measured values and those expected for the calibrated version; these differences are, for the non-calibrated version, $+5 \%$ and $+102 \%$ for the years $2016 / 2017$ and $2017 / 2018$, respectively, and between $-33 \%$ and $+34 \%$ for the calibrated version. Furthermore, the measured and modeled volumes that do not exceed $1.78 \times 10^{6} \mathrm{~m}^{3} /$ year $^{-1}$ remain well below the dam's siltation rate of $9.49 \times 10^{6} \mathrm{~m}^{3} /$ year $^{-1}$, obtained from a continuous bathymetry survey, which means that only $18 \%$ of the dam's sediment comes from upstream. This seems very low because it is calculated from only two years. The main hypothesis that is formulated is that the majority of the sediments of the dam most probably come from the erosion of its banks.

\section{Concluding Remarks}

This Special Issue shows the great interest of the scientific community in investigating how to characterize the environmental impact of anthropogenic and climatic changes, and also determining which is the main source of changes depending on the regional situations and thematic issues. This first issue might lead to following issues on more specific topics, according to, for instance, the 23 unsolved problems in hydrology [26], or future issues that are focused on different regional areas. Future issues on this topic might also focus more on water resources challenges in urban tropical and Mediterranean areas, which constitute increasing shares of the populations in these areas. These densely populated areas are also often localized near the coast, which brings up specific concerns about the coastal damages caused by human interventions (such as dams and irrigations) and sea level rising on the inland water cycle [27]. The impact of global warming and the increasing occurrence of extreme events on runoff generation and discharge dynamics must also be addressed in the future. Changes in the water-holding capacity of soil (at the point scale) and basins (at the regional scale) will impact river regimes through the evolution of runoff and recession coefficients as indexes of these major possible dynamics.

Conflicts of Interest: The authors declare no conflict of interest.

\section{References}

1. Tramblay, Y.; Koutroulis, A.; Samaniego, L.; Vicente-Serrano, S.M.; Volaire, F.; Boone, A.; Le Page, M.; Carmen Llasat, M.; Albergel, C.; Burak, S.; et al. Challenges for drought assessment in the mediterranean region under future climate scenarios. Earth Sci. Rev. 2020, 210, 103348. [CrossRef]

2. Song, X.P.; Hansen, M.C.; Stehman, S.V.; Potapov, P.V.; Tyukania, A.; Vermote, E.F.; Townshend, J.R. Global land change from 1982 to 2016. Nature 2018, 560, 639-643. [CrossRef]

3. Eccles, R.; Zhang, H.; Hamilton, D. A review of the effects of climate change on riverine flooding in subtropical and tropical regions. J. Water Clim. Chang. 2019, 10, 687-707. [CrossRef]

4. Tramblay, Y.; Llasat, M.C.; Randin, C.; Coppola, E. Climate change impacts on water resources in the Mediterranean. Reg. Environ. Chang. 2020, 20, 83. [CrossRef]

5. Mahé, G.; Dray, A.; Paturel, J.E.; Crès, A.; Koné, F.; Manga, M.; Crès, F.N.; Djoukam, J.; Maïga, A.H.; Ouédraogo, M.; et al. Climatic and anthropogenic impacts on the flow regime of the Nakambe River in Burkina. In Bridging the Gap between Research and Practice, Proceedings of the Fourth International FRIEND Conference, Cape Town, South Africa, 18-22 March 2002; Van Lannen, H., Demuth, S., Eds.; IAHS Publ. 274; IAHS Publications: Oxfordshire, UK, 2002; pp. 69-76. Available online: https://iahs.info/uploads/dms/ 12264.14-Mahe-et-al.--F28--pp.-69-76-revised.pdf (accessed on 22 March 2020).

6. Descroix, L.; Guichard, F.; Grippa, M.; Lambert, L.; Panthou, J.; Mahe, G.; Gal, L.; Dardel, C.; Quantin, G.; Kergoat, L.; et al. Surface hydrology evolution in the Sahelo-Sudanian stripe: An updated review. Water 2018, 10, 748. [CrossRef]

7. Ribolzi, O.; Evrard, O.; Huon, S.; Rouw, A.; De Silvera, N.; Latsachack, O.; Soulileuth, B.; Lefèvre, I.; Pierret, A. From shifting cultivation to teak plantation: Effect on overland flow and sediment yield in a montane tropical catchment. Sci. Rep. 2017, 12, 1-12. [CrossRef]

8. Toteu, S.F.; Mahé, G.; Moritz, R.; Sracek, O.; Davies, T.C.; Ramasamy, J. Environmental, health and social legacies of mining activities in Sub-Saharan Africa. J. Geochem. Explor. 2020, 209. [CrossRef]

9. Lacombe, G.; Valentin, C.; Sounyafong, P.; Rouw, A.; De Soulileuth, B.; Silvera, N.; Pierret, A.; Sengtaheuanghoung, O.; Ribolzi, O. 2018. Linking crop structure, throughfall, soil surface conditions, runoff and soil detachment: 10 land uses analyzed in Northern Laos. Sci. Total Environ. 2017, 616-617, 1330-1338. [CrossRef] 
10. Morán-Ordóñez, A.; Duane, A.; Gil-Tena, A.; De Cáceres, M.; Aquilué, N.; Guerra, C.; Geijzendorffer, I.R.; Fortin, M.-J.; Brotons, L. Future impact of climate extremes in the Mediterranean: Soil erosion projections when fire and extreme rainfall meet. Land Degrad. Dev. 2020, 31, 3040-3054. [CrossRef]

11. Ma, X.; Lacombe, G.; Harrison, R.; Xu, J.; van Noordwijk, M. Expanding Rubber Plantations in Southern China: Evidence for Hydrological Impacts. Water 2019, 11, 651. [CrossRef]

12. Song, L.; Boithias, L.; Sengtaheuanghoung, O.; Oeurng, C.; Valentin, C.; Souksavath, B.; Sounyafong, P.; de Rouw, A.; Soulileuth, B.; Silvera, N.; et al. Understory Limits Surface Runoff and Soil Loss in Teak Tree Plantations of Northern Lao PDR. Water 2020, 12, 2327. [CrossRef]

13. Laraque, A.; Lopez, J.; Yepez, S.; Georgescu, P. Water and Sediment Budget of Casiquiare Channel Linking Orinoco and Amazon Catchments, Venezuela. Water 2019, 11, 2068. [CrossRef]

14. Hout, R.; Maleval, V.; Mahe, G.; Rouvellac, E.; Crouzevialle, R.; Cerbelaud, F. UAV and LiDAR Data in the Service of Bank Gully Erosion Measurement in Rambla de Algeciras Lakeshore. Water 2020, 12, 2748. [CrossRef]

15. Laraque, A.; Moukandi N’kaya, G.; Orange, D.; Tshimanga, R.; Tshitenge, J.; Mahé, G.; Nguimalet, C.; Trigg, M.; Yepez, S.; Gulemvuga, G. Recent Budget of Hydroclimatology and Hydrosedimentology of the Congo River in Central Africa. Water 2020, 12, 2613. [CrossRef]

16. Dieulin, C.; Mahé, G.; Paturel, J.; Ejjiyar, S.; Tramblay, Y.; Rouché, N.; EL Mansouri, B. A New 60-Year 1940/1999 Monthly-Gridded Rainfall Data Set for Africa. Water 2019, 11, 387. [CrossRef]

17. Amoussou, E.; Awoye, H.; Totin Vodounon, H.; Obahoundje, S.; Camberlin, P.; Diedhiou, A.; Kouadio, K.; Mahé, G.; Houndénou, C.; Boko, M. Climate and Extreme Rainfall Events in the Mono River Basin (West Africa): Investigating Future Changes with Regional Climate Models. Water 2020, 12, 833. [CrossRef]

18. Bodian, A.; Diop, L.; Panthou, G.; Dacosta, H.; Deme, A.; Dezetter, A.; Ndiaye, P.; Diouf, I.; Vischel, T. Recent Trend in Hydroclimatic Conditions in the Senegal River Basin. Water 2020, 12, 436. [CrossRef]

19. Yilmaz, M.; Onoz, B. A Comparative Study of Statistical Methods for Daily Streamflow Estimation at Ungauged Basins in Turkey. Water 2020, 12, 459. [CrossRef]

20. Ebodé, V.; Mahé, G.; Dzana, J.; Amougou, J. Anthropization and Climate Change: Impact on the Discharges of Forest Watersheds in Central Africa. Water 2020, 12, 2718. [CrossRef]

21. Ezzaouini, M.; Mahé, G.; Kacimi, I.; Zerouali, A. Comparison of the MUSLE Model and Two Years of Solid Transport Measurement, in the Bouregreg Basin, and Impact on the Sedimentation in the Sidi Mohamed Ben Abdellah Reservoir, Morocco. Water 2020, 12, 1882. [CrossRef]

22. Bader, J.; Dacosta, H.; Pouget, J. Seasonal Variations of the Depletion Factor during Recession Periods in the Senegal, Gambia and Niger Watersheds. Water 2020, 12, 2520. [CrossRef]

23. Descroix, L.; Faty, B.; Manga, S.; Diedhiou, A.; Lambert, L.A.; Soumaré, S.; Andrieu, J.; Ogilvie, A.; Fall, A.; Mahé, G.; et al. Are the Fouta Djallon Highlands Still the Water Tower of West Africa? Water 2020, 12, 2968. [CrossRef]

24. Descroix, L.; Sané, Y.; Thior, M.; Manga, S.; Ba, B.; Mingou, J.; Mendy, V.; Coly, S.; Dièye, A.; Badiane, A.; et al. Inverse Estuaries in West Africa: Evidence of the Rainfall Recovery? Water 2020, 12, 647. [CrossRef]

25. Cavus, Y.; Aksoy, H. Spatial Drought Characterization for Seyhan River Basin in the Mediterranean Region of Turkey. Water 2019, 11, 1331. [CrossRef]

26. Blöschl, G.; Bierkens, M.F.; Chambel, A.; Cudennec, C.; Destouni, G.; Fiori, A.; Kirchner, J.W.; McDonnell, J.J.; Savenije, H.H.; Sivapalan, M.; et al. Twenty-three unsolved problems in hydrology (UPH)—A community perspective. Hydrol. Sci. J. 2019, 64, 1141-1158. [CrossRef]

27. Hzami, A.; Heggy, E.; Amrouni, O.; Mahe, G.; Maanan, M.; Abdeljaouad, S. Alarming coastal vulnerability of the deltaic and sandy beaches of North Africa. Nat. Sci. Rep. 2021, 11, 2320. [CrossRef] [PubMed] 